\title{
Tree and cold storage influence on incidence of albedo breakdown, textural properties of the rind and fruit quality in 'Washington Navel' orange
}

\author{
Saeed Ahmad ${ }^{1,2, \star}$, Zora Singh ${ }^{1}$ and Zafar Iqbal ${ }^{1,3}$ \\ 1 Curtin Horticulture Research Laboratory, Department of Environment and Agriculture, School of Sciences, Faculty of Science \\ and Engineering, Curtin University, GPO Box U 1987, Perth, 6845 WA, Australia \\ 2 Institute of Horticultural Sciences, University of Agriculture Faisalabad, 38040, Pakistan \\ 3 University College of Agriculture, University of Sargodha, Pakistan
}

Received 29 October 2015 - Accepted 17 December 2015

\begin{abstract}
Introduction. Albedo breakdown (AB) causes serious economic losses to sweet orange growers. The growers practice delayed harvesting (tree storage) to extend the fresh fruit supply to market. We investigated the effects of tree storage and cold storage on $\mathrm{AB}$ incidence, textural properties of the rind and fruit quality. Materials and methods. Fruit of 'Washington Navel' orange were harvested at the commercial maturity stage ( $3^{\text {rd }}$ July) and then 31 , 62 and 93 days after the harvest. The $\mathrm{AB}$ incidence, textural properties of the rind and fruit quality were assessed in one lot of fruit after harvest and a second lot after 31, 62 and 93 days of cold storage $\left(5^{\circ} \mathrm{C}\right)$. Results and discussion. The AB incidence increased from $65 \%$ to $89 \%$ from the first to the last harvest, respectively. Extended storage periods reduced rind hardness and fruit firmness, and increased the rind tensile force irrespective of the storage type. The rind hardness, tensile force and fruit firmness were higher in cold-stored fruit than fruit stored for 93 days on the tree. The soluble solids concentration: titratable acidity (SSC:TA) ratio in juice increased with the extended storage period in both types of storage. The increase in SSC:TA was more pronounced at 62 and 93 days in cold-stored than tree-stored fruit. The concentrations of fructose and glucose in the juice of fruit stored on the tree for 93 days were higher than in the cold-stored fruit, and sucrose showed the reverse trend. Conclusion. The cold-stored fruit exhibited a higher rind hardness, rind tensile force, firmness and SCC:TA ratio, lower concentrations of citric acid, malic acid, fructose and glucose, and lower AB incidence than the tree-stored fruit. These findings indicate a preference for cold storage over tree storage for the orange fruit quality.
\end{abstract}

Keywords: Australia / sweet orange / Citrus sinensis L. / albedo breakdown / sugar composition / fruit rind texture / ripening

Résumé - Influence de la conservation sur l'arbre ou au froid des oranges « Navel de Washington » sur
l'incidence des désordres d'albédo, les propriétés de texture de la peau et la qualité des fruits. Introduction
Les désordres d'albédo $(\mathrm{AB})$ provoquent de lourdes pertes économiques pour les producteurs d'oranges douces. La
pratique courante des producteurs pour retarder la récolte (stockage sur l'arbre) permet d'étendre l'offre en fruits frais
sur le marché. Nous avons étudié les effets du stockage sur l'arbre ou au froid sur l'incidence d'AB, sur les propriétés
de texture de la peau et la qualité des fruits. Matériel et méthodes. Les oranges 'Washington Navel' ont été récoltées
au stade de maturité commerciale $(3$ juillet), puis 31,62 et 93 jours après la récolte. L'incidence d'AB, les propriétés
de texture de la peau et la qualité des fruits ont été évalués à partir d'un lot de fruits juste après la récolte et d'un autre
lot stocké froid $\left(5^{\circ} \mathrm{C}\right)$ pendant 31,62 et 93 jours. Résultats et discussion. L'incidence d'AB a augmenté de $65 \%$ à
$89 \%$ entre la première et la dernière récolte, respectivement. Les longues périodes de stockage ont réduit la rusticité
de la peau, la fermeté des fruits et ont augmenté la force de tension de la peau du fruit que le stockage soit sur l'arbre
ou au froid. La rusticité de la peau, la force de tension et la fermeté des fruits ont été plus élevées pour les fruits
entreposés au froid que pour ceux conservés pendant 93 jours sur l'arbre. Le rapport entre la concentration en solides
solubles et l'acidité titrable (SSC:TA) des jus d'orange a augmenté avec le temps dans les deux types de stockage.

^ Corresponding author: sandhu100hasan@yahoo.com 
L'augmentation du rapport SSC: TA a été plus prononcé à 62 et 93 jours de stockage au froid que pour le stockage sur l'arbre. Les concentrations de fructose et de glucose dans le jus des oranges stockées 93 jours sur l'arbre ont été plus élevées que celles des fruits stockés au froid. La tendance inverse a été trouvée pour le saccharose. Conclusion. L'orange stockée au froid présente une peau plus ferme, plus résistante à la tension, une fermeté et un rapport SSC: TA plus élevés, de plus faibles concentrations d'acide citrique, d'acide malique, de fructose, de glucose, ainsi qu'une incidence d'AB plus faible que l'orange conservée sur l'arbre. Ces résultats indiquent la préférence du stockage au froid pour la qualité des oranges.

Mots clés : Australie / orange douce / Citrus sinensis L. / désordre d'albédo / composition en sucres / texture de la peau du fruit / mûrissement

\section{Introduction}

Harvest maturity affects quality and post-harvest life in a range of fruit crops such as citrus [1], banana [2], apple [3], plum [4] and mango [5]. Shortage of labour, particularly in the peak harvesting season, the limited capacity of pack houses and cold storage, as well as extending the period of fresh fruit supply of 'Washington Navel' oranges to market compel many citrus growers to hold fruit on the tree rather in than cold storage. Delayed harvest (tree storage) leads to over-ripening of the fruit, which has the potential to reduce the storage life and fruit quality. Late harvest reduced the return bloom, increased fruit drop and decreased fruit yield in 'Valencia' oranges [6-9].

Delayed harvest in sweet oranges decreased the juice content and acidity to unacceptable levels [9]. It is also claimed that tree storage of 'Jincheng' orange beyond early March reduced the soluble solids concentration (SSC) and ascorbic acid [10]. 'Navel' orange fruit harvested one month after harvest maturity showed a marked increase in the taste, SSC and soluble solids: titratable acidity (SSC:TA) ratio, but the juice content was reduced [11]. Peel firmness is another important quality parameter and peel firmness, tensile and compression values of different citrus cultivars showed no relationship between harvest maturity and the harvesting date [12].

Earlier, spray application of gibberellic acid $\left(\mathrm{GA}_{3}\right)$ was reported to be effective in delaying the colour development and harvesting in sweet oranges and mandarins [13-15]. Previously, it was reported that 'Mosambi' sweet orange fruit can be stored on the tree for 231 days with spray application of $\mathrm{GA}_{3}\left(30 \mathrm{mg} \mathrm{L}^{-1}\right)$ along with $1 \%$ urea [16]. The research work reported on the effects of tree storage on the fruit quality of sweet orange is scant and inconclusive, whilst no research work has been reported on the comparative effects of tree storage and cold storage on fruit quality and the rind texture of sweet orange.

Oranges can be stored at $2-7{ }^{\circ} \mathrm{C}$ for $8-12$ weeks, depending on the cultivar and region of production [17]. 'Washington Navel' and 'Egyptian Balady' orange fruit retained their eating quality for up to 4 and 3 months in cold storage, respectively [18]. 'Tangor' citrus fruit stored for three months at a temperature between 5 and $11{ }^{\circ} \mathrm{C}$ kept their marketable qualities and even improved in colour and taste [19]. Early harvest of 'Valencia' oranges in April has been reported to extend storage life at $6{ }^{\circ} \mathrm{C}$ with $85-90 \%$ relative humidity 6 months longer than late harvest in May [20]. Cold storage positively influ- enced vitamin $\mathrm{C}$ and antioxidant capacity in non-pigmented cultivars of sweet orange [21].

Albedo breakdown is a physiological disorder with cracks in the internal white tissues (albedo) causing puffiness in the peel of sweet oranges, and causes considerable losses ranging from 10 to $90 \%$ of the crop [22]. The incidence of albedo breakdown has been reported to be influenced by the rootstock, regulated deficit irrigation, foliar application of $\mathrm{GA}_{3}$ in summer, and mineral nutrition [23]. However, no research work has been reported on the effects of the maturity/ripeness stage at harvest on the incidence of albedo breakdown in sweet orange.

The effects of tree storage alone and in comparison with cold storage on the incidence of albedo breakdown, textural properties of the rind and fruit quality are yet to be investigated. We hypothesised that delayed harvest and cold storage will affect the incidence of the albedo breakdown, storage life, quality and textural properties of the rind in sweet orange fruit. These observations prompted us to investigate the comparative effects of tree storage (TS) and cold storage (CS) on the quality and rind textural properties of 'Washington Navel' orange fruit.

\section{Materials and methods}

\subsection{Plant material}

Uniform and twenty-four-year-old 'Washington Navel' orange trees grafted on trifoliate rootstock growing in a commercial orchard in Gingin (latitude $31^{\circ} 21^{\prime} \mathrm{S}$, longitude $155^{\circ} 55^{\prime} \mathrm{E}$ ), Western Australia, were used for the experiment. The trees were planted with $7.5 \mathrm{~m}$ between rows and $2.7 \mathrm{~m}$ between trees with rows in a north-south row direction. The soil of the orchard was sandy loam. All the experimental trees received similar cultural practices including irrigation, fertilisers, plant protection and weed control, except harvest dates [23].

\subsection{Treatments and experimental layout}

Fruits were harvested at commercial harvest maturity $(\mathrm{CH})$ assessed by the appropriate SSC:TA ratio on $3^{\text {rd }}$ July and 31, 62 and 93 days after harvest maturity (DACH) to evaluate the effects of tree storage. To avoid fruit-thinning effects, at each harvest date 50 fruits were harvested from 10 trees, which 
constituted a single replication. For cold storage, fruits were harvested at $\mathrm{CH}$ on $3^{\text {rd }} \mathrm{July}$, and stored at $5{ }^{\circ} \mathrm{C}$ for 93 days. Fifty fruits were treated as an experimental unit. The incidence of albedo breakdown, rind texture and various parameters of fruit quality were assessed at $\mathrm{CH}(0), 31,62$ and 93 days after cold or tree storage. The experimental design was a two-factor factorial design including storage type (TS and CS) and the storage period. All treatments were replicated three times with 50 fruits in each replication.

\subsection{Quality parameters}

\subsubsection{Incidence of albedo breakdown (AB)}

At every harvest date, the fruit with $\mathrm{AB}$ were counted and per cent incidence of albedo breakdown was calculated for each replication.

\subsubsection{Rind texture}

Textural properties of the rind such as rind hardness (rind puncture), tensile force and fruit firmness were determined using a texture analyser (TA Plus, AMETEK Lloyd Instruments Ltd., Hampshire, UK) interfaced with a personal computer with Nexygen ${ }^{\circledR}$ software [23].

\subsubsection{Rind puncture test}

A uniform piece of rind $(2.5 \mathrm{~cm}$ wide and $0.6 \mathrm{~cm}$ thick) was removed from every fruit with a Slicer (Zyliss Easy Slice $2^{\prime \prime}$ folding mandoline slicer, Swiss) to determine the rind hardness. Ten fruits from each replication were tested and the average was calculated. The rind sample was placed onto the flat plate. A 4-mm diameter Magness-Taylor probe, with a $500 \mathrm{~N}$ load cell on, punctured the rind at a crosshead speed of $50 \mathrm{~mm} \mathrm{~min}{ }^{-1}$. Hardness is the maximum force of the first penetration when the rind sample is in contact with the probe at $70 \%$ of the rind sample thickness [23].

\subsubsection{Rind tensile strength test}

A rind sample section of $2.5 \mathrm{~cm}$ wide $\times 5.0 \mathrm{~cm}$ length $\times$ $0.6 \mathrm{~cm}$ thick was removed from each fruit using the slicer to give uniform sections. A sample was held using two clamps. One clamp was fixed to the base of the machine while another one was attached to the moveable load cell. The rind sample was subjected to axial tensile loading until rind deflection of $10 \mathrm{~mm}$ at the crosshead speed of $100 \mathrm{~mm} \mathrm{~min}^{-1}$ and preloads of $10 \mathrm{~N}$. The rind tensile strength was calculated at the maximum load and limit points where the rind deflection occurred. Rind samples were collected from the ten fruits from each replication and the average was calculated and expressed in newton $(\mathrm{N})[23]$.

\subsubsection{Fruit compression test}

Fruit with a height of about $8.5 \mathrm{~cm}$ were used for each compression test. Each fruit was placed between two flat plates with the stem axis perpendicular to the plate. The crosshead speed was $200 \mathrm{~mm} \mathrm{~min}^{-1}$. This test was completed at strain of $25 \%$ of the fruit height. Ten fruits in each replication were used and the average was calculated and expressed in newtons $(\mathrm{N})$ [23].

\subsubsection{Fruit color}

The Commission Internationale de l'Eclairage (CIE) units using a HunterLab ColorFlex $45^{\circ} / 0^{\circ}$ spectrophotometer (HunterLab ColorFlex, Hunter Associates Inc., Reston, Virginia, USA) using the $15-\mathrm{mm}$ aperture were used to record the fruit skin color from four equatorial regions of the fruit as CIE $L^{*}, a^{*}, b^{*}$ values [24].

\subsubsection{Soluble solids concentration (SSC), titrable acidity (TA) and SSC:TA ratio}

SSC of fruit juice was determined using an infrared refractometer (Atago-Palette PR101, Atago Co. Ltd., Itabashi-Ku, Tokyo, Japan) at $20^{\circ} \mathrm{C}$ and expressed in ${ }^{\circ}$ Brix. Fruit juice was titrated against $0.1 \mathrm{~N} \mathrm{NaOH}$ solution using phenolphthalein as an indicator to $\mathrm{pH} 8.2$ to determine TA. TA was expressed as $\%$ citric acid. The SSC:TA ratio was calculated by dividing the TA by SSC values [23].

\subsubsection{Individual sugars and organic acids}

The individual sugars and organic acids were determined by following the method previously described [5]. Freshly extracted juice was diluted with water $(1: 19)$ prior to centrifugation at $5000 \mathrm{rpm}$ for $10 \mathrm{~min}$ using a centrifuge (Eppendorf Centrifuge 5810R, Hamburg, Germany ). A part of the supernatant was filtered through a $0.22-\mu$ m nylon True ${ }^{\mathrm{TM}}$ syringe filter [Alltech Associates (Australia) Ltd., NSW, Australia] and the filtrate was collected in a glass vial and used for high-performance liquid chromatography (HPLC) analysis.

The concentrations of the predominant sugars and organic acids were determined by using a high-performance liquid chromatography (HPLC) system (Waters, Milford, MA, USA) fitted with a fast carbohydrate column, $100 \times 7.8 \mathrm{~mm}$ internal diameter (Bio Rad Laboratories, Hercules, CA, USA) and using a refractive index detector (Waters 2414, Milford, MA, USA). The separation of different organic acids was achieved on an Aminex $87 \mathrm{X}-\mathrm{H}$ column, $300 \times 7.8 \mathrm{~mm}$ i.d. (Bio Rad Laboratories) and a UV-absorbance detector (Waters 2487) at $214 \mathrm{~nm}$. All the conditions of analysis including the mobile phase and its flow rate as well as identification of chromatic graphic peaks were similar to those reported earlier [5]. The data were collected and processed with Breeze ${ }^{\circledR} 3.30$ software (Waters, Milford, MA, USA). The concentrations of different sugars (fructose, glucose, sucrose) and major organic acids (citric and malic) in the fruit juice were expressed in $\mathrm{g}$ $100 \mathrm{~mL}^{-1}$. 
Table I. Concentrations of citric acid and malic acid in the juice of 'Washington Navel' orange fruit influenced by the storage type and period. Values are means of 10 fruits per replication $(n=3)(\mathrm{CH}$ : commercial harvest; DACH: days after commercial harvest; NS: not significant; ST: storage type; SP: storage period).

\begin{tabular}{cccccc}
\hline \multicolumn{5}{c}{ Citric acid $\left(\mathrm{g} 100 \mathrm{~mL}^{-1}\right)$} \\
\hline Storage type & $\mathrm{CH}$ & $31 \mathrm{DACH}$ & $62 \mathrm{DACH}$ & $93 \mathrm{DACH}$ & Mean $(\mathrm{ST})$ \\
Tree storage & 0.65 & 0.53 & 0.52 & 0.33 & 0.51 \\
Cold storage & 0.65 & 0.51 & 0.39 & 0.34 & 0.47 \\
Mean $(\mathrm{SP})$ & 0.65 & 0.52 & 0.45 & 0.34 & \\
\hline LSD $(P=0.05) \mathrm{ST}=\mathrm{NS}, \mathrm{SP}=0.05, \mathrm{ST} \times \mathrm{SP}=\mathrm{NS}$. & \\
\hline \multicolumn{7}{c}{ Malic acid $\left(\mathrm{g} 100 \mathrm{~mL}^{-1}\right)$} \\
\hline Storage type & $\mathrm{CH}$ & $31 \mathrm{DACH}$ & $62 \mathrm{DACH}$ & $93 \mathrm{DACH}$ & Mean $(\mathrm{ST})$ \\
Tree storage & 0.086 & 0.120 & 0.210 & 0.270 & 0.174 \\
Cold storage & 0.086 & 0.120 & 0.120 & 0.340 & 0.169 \\
Mean $(\mathrm{SP})$ & 0.086 & 0.120 & 0.168 & 0.300 &
\end{tabular}

\subsubsection{Vitamin $\mathrm{C}$ and total phenolics}

Vitamin C was estimated from the fruit juice by following a previously used method [24]. Vitamin C concentrations were calculated using a standard curve of L-ascorbic acid and expressed in $\mathrm{mg} 100 \mathrm{~mL}^{-1}$.

Total phenolic content of fruit juice was determined by using Folin-Ciocalteu reagent following the method previously described [25]. Gallic acid was used as a standard for the calibration curve. The concentrations of total phenolics were calculated and expressed in $\mathrm{mg}$ gallic acid equivalent (GAE) $100 \mathrm{~mL}^{-1}$ juice.

\subsection{Statistical analysis}

The data were subjected to two-way analysis of variance (ANOVA) employing GenStat Release 11.1 (VSN International Ltd., Hemel Hempstead, UK). Least significant differences (Fisher's LSD) were calculated with the significant F test $(P=0.05)$. The effects of different treatments on various parameters and their interactions were assessed with ANOVA.

\section{Results and discussion}

\subsection{Incidence of albedo breakdown}

Prolonged fruit storage on the tree significantly elevated the incidence of $\mathrm{AB}$ (figure 1). The incidence of $\mathrm{AB}$ increased dramatically (65.00 to $89.33 \%$ ) from commercial harvest $(\mathrm{CH})$ to 93 days after commercial harvest (DACH). There was no increase in the incidence of $\mathrm{AB}$ in cold-stored fruit up to 93 days. Possibly, the increased incidence of $\mathrm{AB}$ with prolonged tree storage of fruit may be associated with over-ripening, natural ageing and the senescence processes of orange fruit [26, 27].

\subsection{Fruit color}

The storage type and storage period significantly influenced the $L^{*}$ (whiteness) and $b^{*}$ (yellowness) values, but $a^{*}$

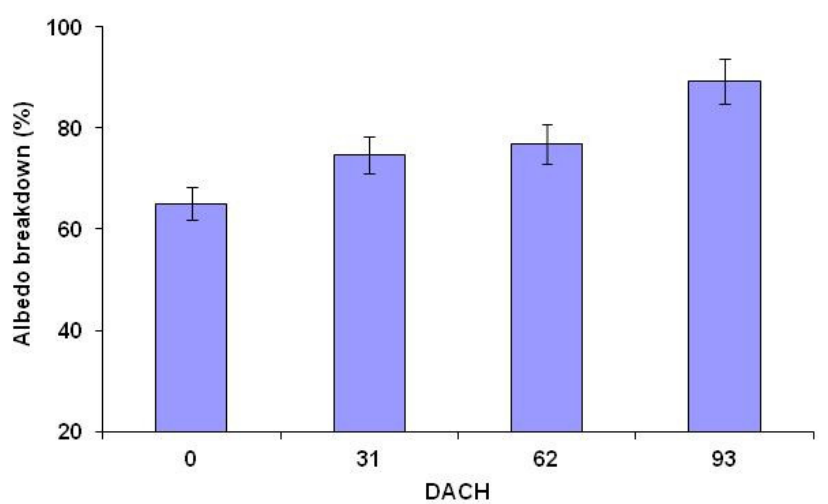

Figure 1. Effect of tree storage on the incidence of albedo breakdown in 'Washington Navel' sweet orange. Values are means of 50 fruits per replication ( $n=3$ replications). Vertical bars represent the LSD $(P=0.05)$ (DACH: days after commercial harvest).

(greenness) values were not significantly affected (table I). Both tree and cold storage fruit showed similar effects on $L^{*}$ and $b^{*}$ values. Whiteness (L) and yellowness $\left(b^{*}\right)$ values increased (22. 08 and 32.32 to 37.79 and 41.65 , respectively) from commercial harvest, to 31,62 and $93 \mathrm{DACH}$ on treestored fruit. The same trend was also observed in cold storage, except $L^{*}$ decreased at $62 \mathrm{DACH}$ but increased again at $93 \mathrm{DACH}$. $L^{*}$ and $b^{*}$ increased with the extended period of storage irrespective of the storage type. This increase may be ascribed to the degradation of chlorophyll, and improved biosynthesis of carotenoids due to the advanced ripening process. Similarly, an inverse relationship between chlorophyll and carotenoid biosynthesis during 'Kinnow' mandarin fruit ripening has been reported [28].

\subsection{Rind texture and fruit firmness}

The storage type and storage period significantly influenced the rind hardness, rind tensile force and fruit firmness. There were significant $(P=0.05)$ interactions between the storage type and storage period for rind hardness, rind tensile force and fruit firmness. The extended cold and tree storage 
period exhibited a decline in rind hardness, whilst the trend was the reverse for rind tensile force. Rind hardness and fruit firmness of cold-stored fruit were significantly higher than those stored on the tree irrespective of the storage period (figure $2 A$ ). The extended storage period resulted in reduced rind hardness and fruit firmness (figure 2), which may be ascribed to the rind elasticity force that reaches maximum levels at the mature stage and after this it starts to decrease in several fruit and vegetables [29]. Citrus peel has two sections, the albedo and flavedo (the outer colored portion of citrus fruit peel), which consist of enlarged parenchymatous cells with intercellular space and a compact cellular structure containing an oil gland covered with a layer of natural wax [30]. The hard and waxy structure of the flavedo zone is responsible for the high modulus of elasticity of peel [30]. The extended cold and tree storage period exhibited a decline in rind hardness, whilst the trend was the reverse for rind tensile force. On days 31 and 62 of storage, the rind tensile force was significantly higher in cold-stored fruit than those stored on trees except at day 93.

The rind hardness and fruit firmness indicated by the fruit compression force were significantly reduced as the storage period was extended, irrespective of the storage method (figure $2 A, 2 C$ ). Following 93 days of storage, the tree-stored fruit exhibited more reduced rind hardness and fruit firmness than cold-stored ones, which may be attributed to the storage conditions, particularly the higher temperature, consequently elevated respiration rate and senescence process in the fruit [31]. It may also be attributed to the degradation of pectin polysaccharide chains in the rind cell wall caused by over-ripening and the senescence process in tree-stored fruit. Earlier, it was reported that the strong structural rigidity of the cell wall is due to the formation of pectin polysaccharide, which maintains the cell stabilisation and membrane integrity [32].

The rind tensile force increased as the storage period was extended, irrespective of the storage method of the fruit (figure $2 B$ ). The increased rind tensile force may possibly be attributed to higher water loss from the tissues of the cell wall; an extended storage period consequently increased elasticity.

Comparison of tree-stored and cold-stored fruit showed that in cold storage the physiological activities of the cell wall may be maintained for a long period due to the inhibition in breakdown of pectic substances which are responsible for retaining the fruit texture and remain firmer for a longer period [33]. The low storage temperature and detachment of ripe fruit from the tree slowed down the over-ripening and senescence processes. The textural properties of citrus fruit are dependent on temperature, as fruit stored at low temperature need more force to puncture than those which were stored at higher temperature [34].

\subsection{Soluble solids content (SSC), titrable acidity (TA) and SSC:TA ratio}

The storage type and storage period significantly $(P=$ 0.05 ) affected the SSC, TA and SSC:TA ratio (figure 3). Treestored fruit showed increased SSC from 11.53 to $15.26 \%$ from 0 to 62 days, but a slight reduction in SSC was noted infruit stored on the tree for 93 days. Cold-stored fruit also showed

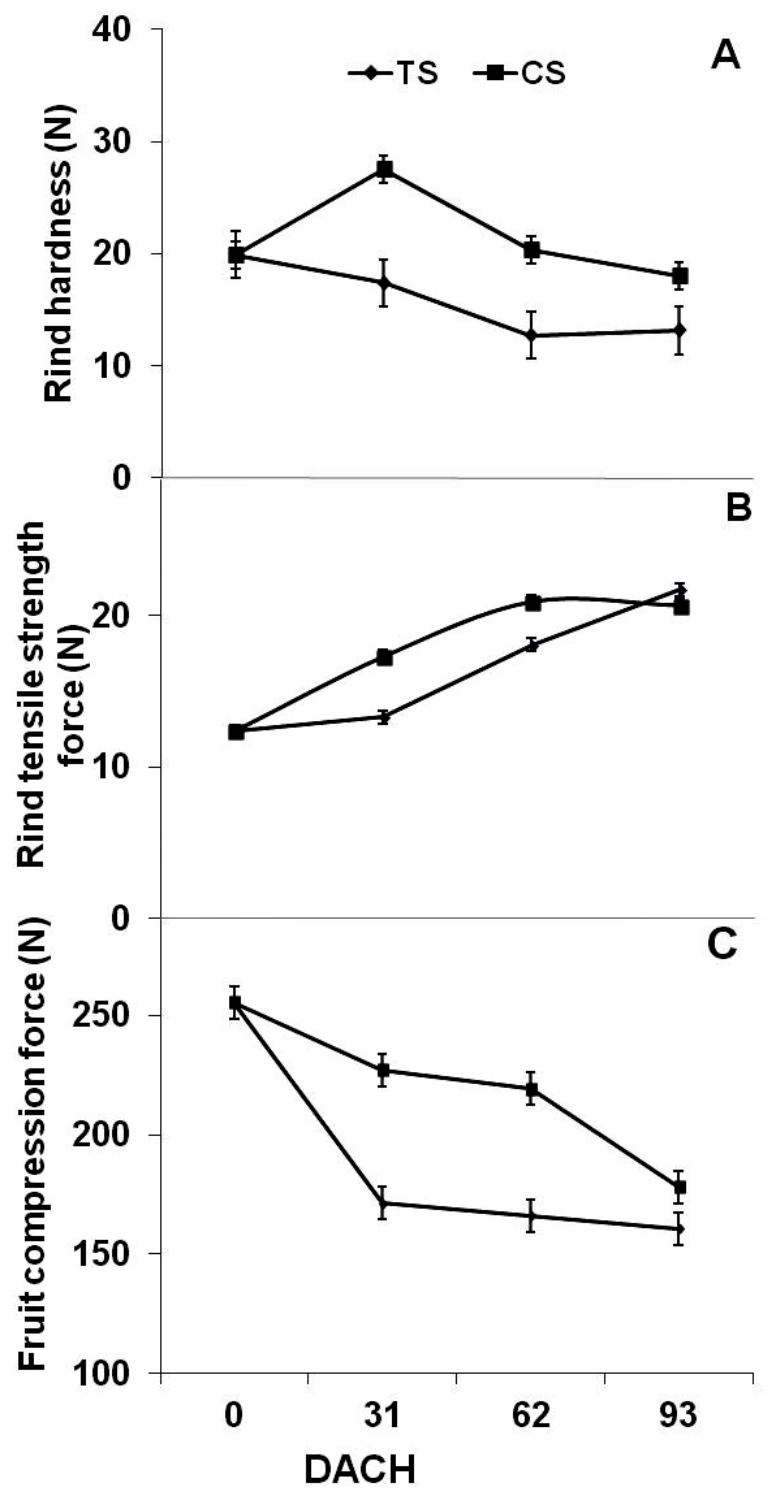

Figure 2. Effects of tree storage (TS) and cold storage (CS) duration on rind properties of 'Washington Navel' sweet oranges. Values are means of 50 fruits per replication ( $n=3$ replications). Vertical bars represent the $\operatorname{LSD}(P=0.05)(\mathrm{DACH}=$ days after commercial harvest).

increased SSC up to 31 days but remained constant up to 93 days. The increase in SSC with extended tree storage may be ascribed to the ripening processes; as it was reported earlier that the SSC in 'Red Blush' grapefruit were at a minimal level during early harvesting dates and increased to the maximum level on January 1, and after that decreased [35]. TA in juice declined as the storage period was extended in both cold- and tree-stored fruit (figure 3). The decline in TA in the juice was more pronounced following 62 and 93 days of cold storage than in tree-stored fruit. It may be ascribed to the decreased concentrations of the predominant organic acids such as citric acid and malic acid in sweet orange fruit (table II). Similarly, the decline in acidity of citrus fruit with advancement of 
Table II. Fruit colour (CIE $L^{*}, a^{*}$ and $b^{*}$ values) of 'Washington Navel' orange influenced by the storage type and period. Values are means of 10 fruits per replication $(n=3)(\mathrm{CH}$ : commercial harvest; DACH: days after commercial harvest; NS: not significant; ST: storage type; SP: storage period).

\begin{tabular}{|c|c|c|c|c|c|}
\hline \multicolumn{6}{|c|}{$L *$} \\
\hline Storage type & $\mathrm{CH}$ & $31 \mathrm{DACH}$ & $62 \mathrm{DACH}$ & $93 \mathrm{DACH}$ & Mean (ST) \\
\hline Tree storage & 22.08 & 24.13 & 35.78 & 37.79 & 29.94 \\
\hline Cold storage & 22.08 & 25.49 & 23.30 & 40.91 & 27.94 \\
\hline Mean (SP) & 22.08 & 24.81 & 29.54 & 39.35 & \\
\hline \multicolumn{6}{|c|}{$\mathrm{LSD}(P=0.05) \mathrm{ST}=0.19, \mathrm{SP}=0.27, \mathrm{ST} \times \mathrm{SP}=0.38$} \\
\hline \multicolumn{6}{|c|}{$a *$} \\
\hline Storage type & $\mathrm{CH}$ & $31 \mathrm{DACH}$ & $62 \mathrm{DACH}$ & $93 \mathrm{DACH}$ & Mean $(\mathrm{ST})$ \\
\hline Tree storage & 23.91 & 24.41 & 24.80 & 23.82 & 24.24 \\
\hline Cold storage & 23.91 & 25.51 & 23.27 & 25.24 & 24.48 \\
\hline Mean (SP) & 23.91 & 24.96 & 24.03 & 24.53 & \\
\hline \multicolumn{6}{|c|}{$\mathrm{LSD}(P=0.05) \mathrm{ST}=\mathrm{NS}, \mathrm{SP}=\mathrm{NS}, \mathrm{ST} \times \mathrm{SP}=\mathrm{NS}$} \\
\hline \multicolumn{6}{|c|}{$b *$} \\
\hline Storage type & $\mathrm{CH}$ & $31 \mathrm{DACH}$ & $62 \mathrm{DACH}$ & $93 \mathrm{DACH}$ & Mean (ST) \\
\hline Tree storage & 32.32 & 35.00 & 33.88 & 41.65 & 35.71 \\
\hline Cold storage & 32.32 & 25.93 & 32.44 & 44.47 & 33.86 \\
\hline Mean (SP) & 32.32 & 30.47 & 33.16 & 43.19 & \\
\hline
\end{tabular}

fruit ripening has been reported in 'Hamlin' oranges [16]. The SSC:TA in juice increased as the storage period was extended in both cold and tree storage of the fruit (figure $3 C$ ). However, the increase in SSC:TA was more pronounced in cold-stored than tree-stored fruit following 62 and 93 days of storage. The increased SSC:TA ratio may be ascribed to the increased concentration of SCC and reduced levels of TA with the extended tree and cold storage period (figure 3) which are physiochemical processes which mostly continue up to maturity, ripening and senescence, observed in 'Tarocco' oranges [36].

\subsection{Fructose, glucose and sucrose}

The storage type and storage period significantly affected the concentrations of fructose, glucose and sucrose in fruit juice, but the interaction between the storage period and storage type was found to be non-significant. The concentrations of fructose and glucose in juice of tree-stored fruit were significantly higher than in fruit stored in the cold for 93 days (figure $4 A$ and $4 B$ ). Following 31, 62 and 93 days of storage, the tree-stored fruit exhibited a significantly higher concentration of sucrose than cold-stored fruit (figure 4C). The higher levels of fructose, glucose and sucrose in tree-stored fruit than cold-stored fruit may possibly be due to the continuous translocation of photosynthates from the leaves to the fruit $[37,38]$. The lower concentrations of fructose in cold-stored fruit than in tree-stored fruit are beneficial, as a high sustained consumption of fructose in the human diet induces dyslipidemia and insulin resistance [39]. Citrus fruit is also a good source of health-promoting substances and additionally, the fruits which have less fructose are considered to be beneficial for human health. Since SSC in fruit are generally correlated with carbohydrate contents, these results suggest that cold storage of citrus helps maintain the fruit metabolism at a low level compared with metabolically active tree-stored fruits.

\subsection{Organic acids}

Citric acid is a major acid in citrus fruit (70-90\% of the total), followed by malic acid and very low concentrations of other acids such as fumaric acid, and succinic and tartaric acids [40]. Therefore, we determined the changes in concentrations of citric acid and malic acid during the storage period, which are the predominant organic acids in sweet orange fruit [1]. The storage period showed significant effects on the concentrations of citric acid in fruit juice, but the storage type and its interaction with the storage period were nonsignificant. The storage period and its interaction with the storage type showed significant effects on the concentrations of malic acid (table II). The concentration of citric acid decreased from $0.65 \mathrm{~g} \mathrm{~mL}^{-1}$ at commercial harvest to 0.33 and $0.34 \mathrm{~g} \mathrm{~mL}^{-1}$ after 93 days of tree and cold storage, respectively (table II). Citric acid has also been reported to decrease in stored 'Pineapple', 'Valencia' and in 'Shamouti' oranges $[41,42]$. The concentration of malic acid increased from $0.086 \mathrm{~g} \mathrm{~mL}^{-1}$ at commercial harvest to 0.27 and $0.34 \mathrm{~g} \mathrm{~mL}^{-1}$ after 93 days of tree and cold storage, respectively (table II). These results are also supported by previous findings [43] where it was observed that citric acid decreased in stored 'Valencia' oranges but malic acid remained stable.

The extended cold or tree storage period of the fruit resulted in increased levels of phenols in the juice, and the increase was more pronounced following 31 days of storage (figure $5 A$ ). Increased levels of total phenolic compounds were noted in sweet orange fruit juice of the cvs Tarocco Messina, Tarocco Meli, Moro and Ovale with an extended 


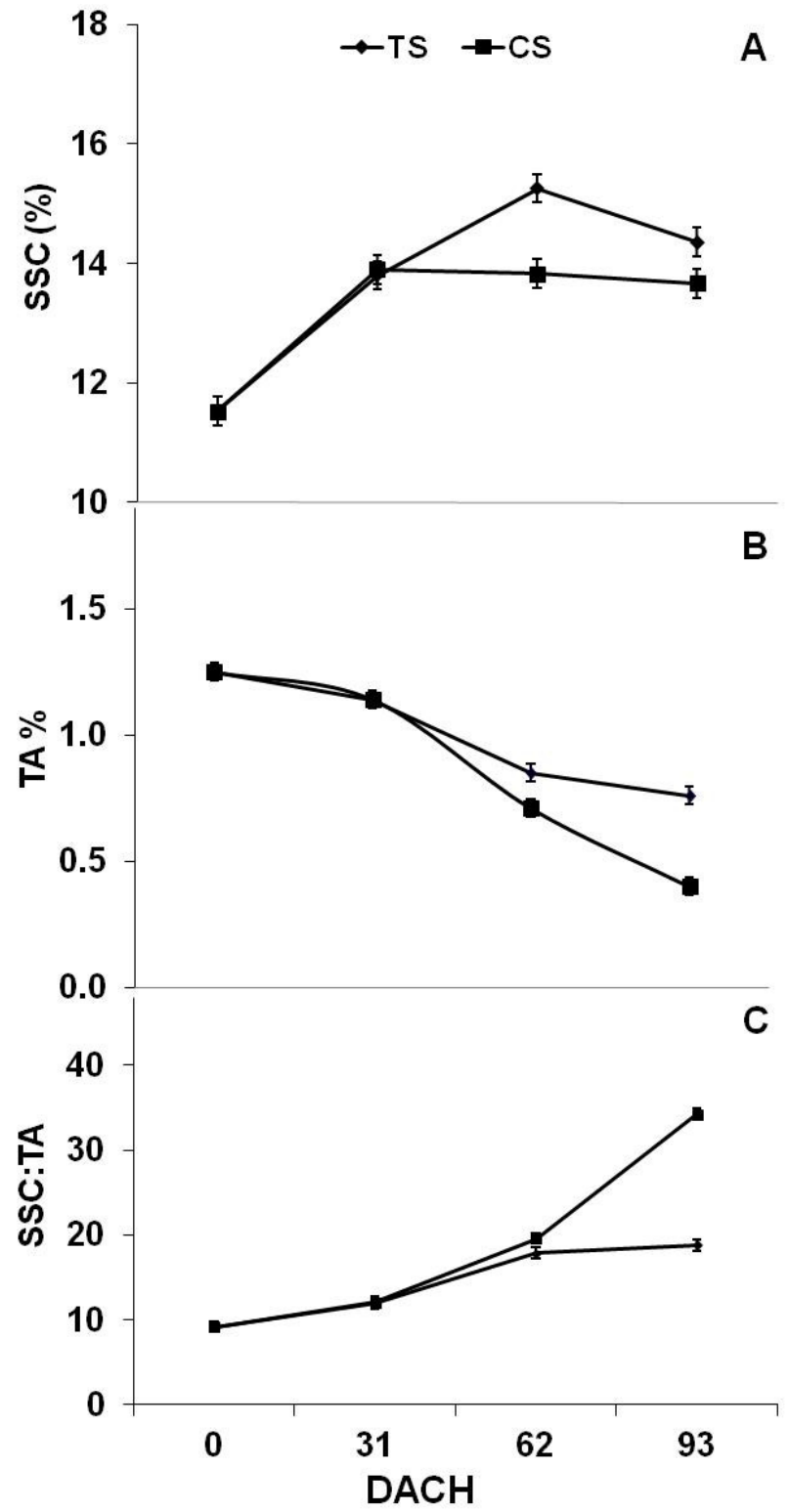

Figure 3. Effects of tree storage (TS) and cold storage (CS) duration on soluble solids concentration (SSC), titratable acidity (TA) and SSC:TA in the juice of 'Washington Navel' sweet orange. Values are means of 50 fruits per replication ( $n=3$ replications). Vertical bars represent the $\operatorname{LSD}(P=0.05)(\mathrm{DACH}=$ days after commercial harvest).

storage period at $6{ }^{\circ} \mathrm{C}$, but this trend was not found in the $\mathrm{cv}$ Valencia [36]. The level of vitamin $\mathrm{C}$ in the juice significantly decreased following 31 days of cold storage and remained at similar levels following 62 and 93 days of cold storage ( $f i g$ ure $5 B$ ). Citrus fruit is rich in vitamin $\mathrm{C}$, but decreased levels of vitamin $\mathrm{C}$ due to cold storage have also been reported in sweet orange [36]. The losses in the levels of vitamin $\mathrm{C}$ in the juice of tree-stored fruit were minimal until $62 \mathrm{DACH}$, but the vitamin $C$ levels declined substantially in fruit-stored on the tree for 93 days (figure $5 B$ ), which may be ascribed to the over-ripening of tree-stored fruit. Similarly, concentrations of

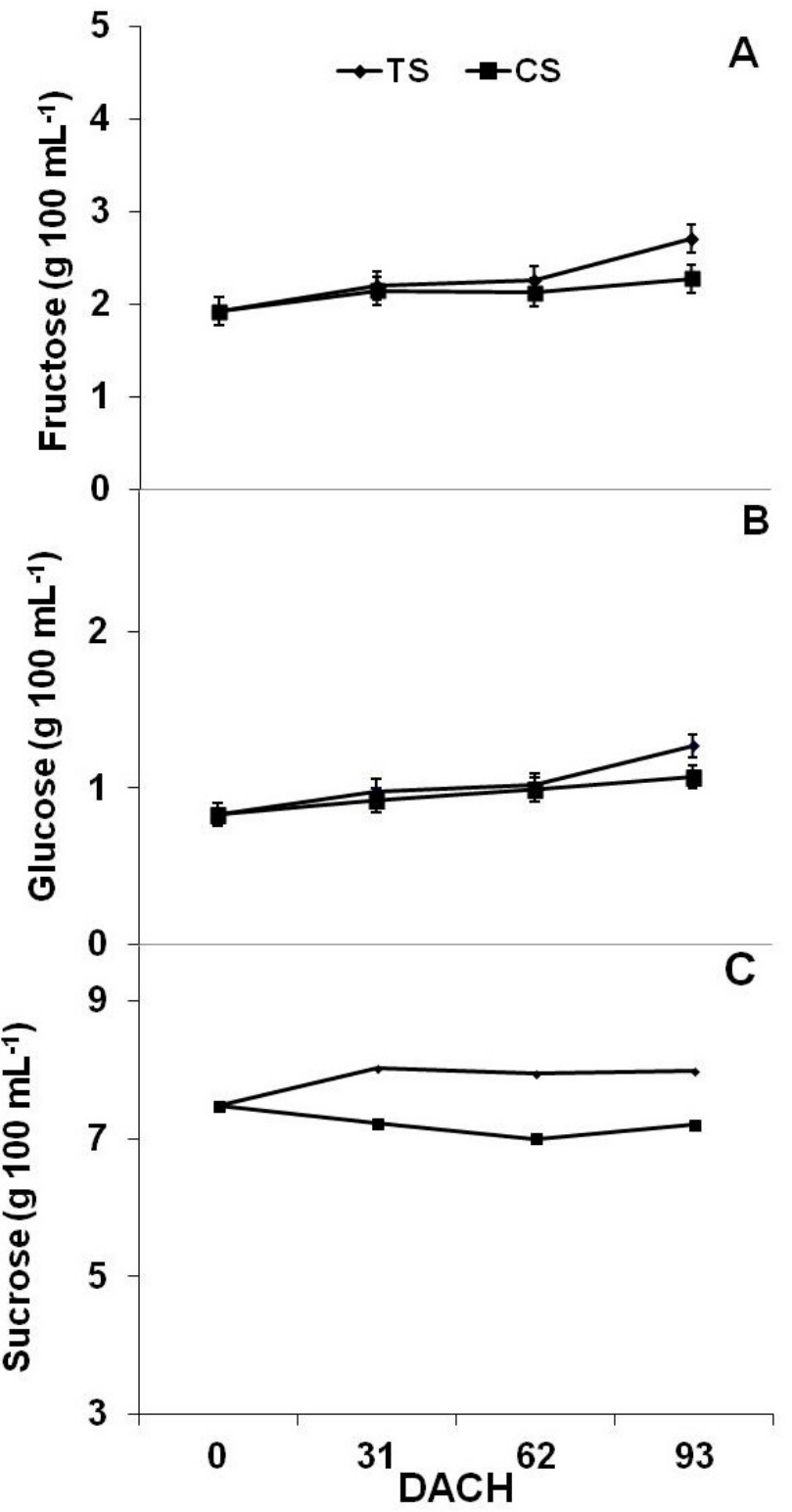

Figure 4. Effects of tree storage (TS) and cold storage (CS) duration on the levels of individual sugars in the juice of 'Washington Navel' sweet orange orange. Values are means of 50 fruits per replication ( $n=3$ replications). Vertical bars represent the $\operatorname{LSD}(P=0.05)$ (DACH $=$ days after commercial harvest).

ascorbate decreased throughout the ripening process in sweet orange fruit [44].

\section{Conclusion}

Cold-stored fruits exhibited a higher rind hardness, rind tensile force, firmness and SCC:TA ratio, and lower concentrations of citric acid, malic acid, fructose, glucose, sucrose and vitamin $C$ than tree-stored fruits. The incidence of albedo breakdown increased with the extended period of tree storage 


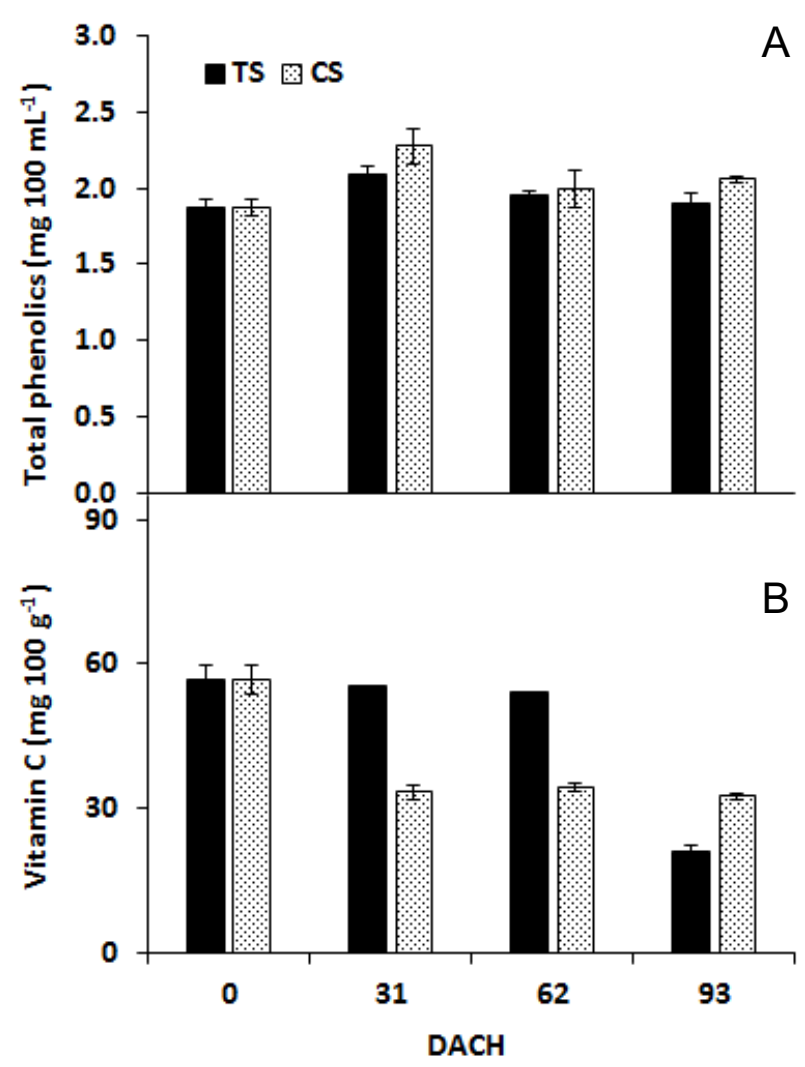

Figure 5. Effects of tree storage (TS) and cold storage (CS) duration on the levels total phenols and vitamin $\mathrm{C}$ in the juice of 'Washington Navel' orange. Values are means of 50 fruits per replication $(n=3$ replications). Vertical bars represent the $\operatorname{LSD}(P=0.05)(\mathrm{DACH}=$ days after commercial harvest).

of the fruit. The effects of tree storage on fruit yield and return bloom need to be further investigated, as tree storage of citrus fruit is known to promote fruit drop and reduce return bloom [6-9].

Acknowledgements. S. Ahmad gratefully acknowledges the Higher Education Commission, Pakistan, for providing financial assistance during his postdoctoral research work. He is also thankful to the Vice Chancellor and the Registrar of the University of Agriculture Faisalabad, Pakistan, for granting the study leave. The authors are thankful to Mr John Marten, Manager, Westeralian Fruits, Gingin, Western Australia, for providing us with experimental trees and fruit for this research work, and to Dr H.D.J. Lalel for assisting in estimation of vitamin C and total phenolics. We also thank Ms Susan Petersen, Senior Technical Officer, for her assistance in biochemical analysis.

\section{References}

[1] Davies F.S., Albrigo L.G., Citrus. CAB International, Wallingford, (1994) UL, pp. 205-225.

[2] Ahmad S., Clark B., Thompson A.K., Banana harvest maturity and fruit position on the quality of ripe fruit, Ann. Appl. Biol. 139 (2001) 329-335.

[3] Valiuskaite A., Kviklien N., Kviklys D., Lanauskas J., Postharvest fruit rot incidence depending on apple maturity, Agron. Res. 4 (2006) 427-431.
[4] Lebrun M., Plotto A., Goodner K., Ducamp M., Baldwin E., Discrimination of mango fruit maturity by volatiles using the electronic nose and gas chromatography, Postharvest Biol. Tech. 48 (2008) 122-131.

[5] Singh S.P., Singh Z., Swinny E.E., Sugars and organic acids in Japanese plums (Prunus salicina Lindell) as influenced by maturation, harvest date, storage temperature and period, Int. J. Food Sci. Tech.44 (2009) 1973-1982.

[6] Hilgeman H.H., Dunlap J.S., Sharp F.O., Effect of time of harvest of Valencia Oranges in Arizona on fruit grade and size and yield the following year, Proc. Amer. Soc. Hort. Sci. 90 (1967) 103-109.

[7] Hilgeman H.H., Dunlap J.S., Sharple G.C., The effect of time of harvest of Valencia oranges on leaf carbohydrate content and subsequent set of fruit, Proc. Amer. Soc. Hort. Sci. 90 (1967) $110-116$.

[8] Albrigo L.G., Impact of late harvest on citrus crop losses and juice quality, Proc. Fla. State Hortic. Soc. 119 (2006) 199-202.

[9] Reuther W., Rios-Castano D., Comparison of growth, maturation and composition of citrus fruits in subtropical California and tropical Columbia, Proc. First Int. Citrus Symp. 1 (1969) 277-300.

[10] Pen C., Zhi C., Lun P.L., Li J.C., Ting C.L., Changes of fruit characteristics during hang-on the tree storage of Jincheng orange cultivar, South China Fruits, 6 (2004) 22-23.

[11] Ke-Ling C., Jian-Jan L., Nan, Q. Shang-mo L, Qing-yi Y., Shao-bing C., Hong-wen L., De-ying Z., Study on quality development of naval orange (Citrus sinensis Osb.) during storage of fruit kept on tree, Southwest China J. Agric. Sci. 18 (2005) 810-813.

[12] Churchill D.B., Sumner H.R., Whitney J.D., Peel strength properties of tree oranges varieties, Transection of the ASAE, (1980) 173-176.

[13] Otmani E.L., Coggins J.R., Growth regulators effects on the retention of quality of stored citrus fruit, Sci Hortic. 45 (1990) 261-272.

[14] Huchche A.D., Naqvi S.A.M.H., Ladaniya M.A., Determination of maturity standards for Nagpur mandarin, National Research Centre for Citrus (ICAR), Annual Report, Nagpur, India, 1992, pp. 43-45.

[15] Ladaniya M.S., Naqvi S.A.M.H., Huchc A.D., Studies on standardization of harvesting, handling and storage techniques of Nagpur mandarin, Annual Report of National Research Centre for citrus, Nagpur, 1992, pp. 43-49.

[16] Thete S.K., Chakrawar V.C., Karanjikar P.Z., On- tree storage of sweet orange fruits through plant growth chemicals, J. Soils Crops. 17(1) (2007) 63-66.

[17] Murata T., Citrus. Postharvest physiology and storage of tropical and subtropical fruits, CAB, International, Edited by Mitra, S. 1997, pp. 21-40.

[18] Isshak Y.M., Eissawy M.T., Khalil R.I., Comparative studies of on -tree and low temperature storage of orange fruits, (1978) Agric. Res. Rev. 56 (1997) 29-37.

[19] Cohen E., Shalo Y., Rosenberger I., Post-harvest behaviour of 'Ortanique' (Topaz) tangor citrus fruit during long-term storage at various temperatures, Sci Hortic. 44 (1990) 235-240.

[20] Pekmezci M., Erkan M., Demirkol A., The effect of harvest and different postharvest applications on the storage of 'Valencia' oranges, Acta Hortic. 398 (1995) 277-284.

[21] Rapisarda P., Bianco M.L., Pannuzzo P., Timpanar N., Effect of cold stoarge on vitamin $\mathrm{C}$, phenloics and antioxidant activity of five orange genotypes [Citrus sinensis (L.) Osbeck]. Postharvest Biol. Tech. 49 (2008) 348-354. 
[22] Bower J.P., Prediction and physiology of creasing, Proc. Int. Soc. Citric. 2 (2000) 1089-1090.

[23] Pham T.T.M., Pre-harvest factors affecting fruit quality in sweet oranges with an emphasis on albedo breakdown, $\mathrm{PhD}$ thesis, Curtin University of Technology WA, Australia, 2009, pp. 1045.

[24] Malik A.U., Singh Z., Pre-storage application of polyamines improves shelf-life and fruit quality in mango, J. Hort. Sci. Biotech. 80 (2005) 363-369.

[25] Scalzo J., Politi A., Pellegrini N., Mezzetti B., Battino M., Plant genotype affects total antioxidant capacity and phenolic contents in fruit, Nutrition, 21 (2005) 207-213.

[26] Dick J., Albedo breakdown observation trial, The Western Australia Citrus News, March, (1995) 2-3.

[27] McIntosh D., Cracking the causes of albedo breakdown, Good Fruit Veg. 9 (1998) 42-43.

[28] Dhillon B.S., Singh Z., Fruit growth and development in citrus, in: Advances in horticulture, Chadha, K.L. \& Pareek, O.P. (Eds.), Malhotra Publishing House, New Delhi, 3, 1993, pp. 1167-1183.

[29] Mayor L., Cunha R.L., Sereno A.M., Relation between mechanical properties and structural changes during osmotic dehydration of pumpkin, Food Res. Int. 40 (2007) 448-460.

[30] Chafer A., Gonzalez-martinez C., Chiralt A.P., Microstructure and vacuum impregnation response of citrus peels, Food Res. Int. 36 (2003) 35-41.

[31] Baldwin A., Citrus fruit in: Biochemistry of fruit ripening, Seymour, G.B., Taylor, J.E. and Trucker, G.A. (Eds.), Chapman \& Hall, 1993, pp. 107-149.

[32] Dong T., Xiao R., Xiao Z., Wang P., Song W., Effect of preharvest application of calcium and boron on dietary fibre, hydrolases and ultrastructure in 'Cara Cara' navel orange (Citrus sinensis L. Osbeck) fruit. Sci Hortic. 121 (2009) 272-277.

[33] Salunkhe D.K. Desai B.D., Stress in harvested products, in: Postharvest biotechnology of fruits, CRC Press, Boca Raton, Florida, 1985, pp. 335-394.

[34] Katsiferis T., Zogzas N., Karathanos V.T., Mechanical properties and structure of unripe oranges during processing of 'spoon sweets', J. Food Eng. 89 (2008) 149-155.
[35] Muhtaseb J., Effect of harvesting date on fruit quality of grapefruit cv. 'Red Blush' under Jordan Valley conditions, Fruits, 62 (2007) 107-113.

[36] Rapisarda P., Elisabetta S., Intelisano S., Storage temperature effects on blood orange fruit quality, J. Agric. Food Chem. 49 (2001) 3230-3235.

[37] Bieleski R.L., Accumulation of sorbital and glucose by leaf slices of Rosaceae, Aust. J. Plant Physiol. 4 (1977) 11-24.

[38] Isshida M., Inaba A., Sobajima Y., Translocated of labelled compounds from leaves into shoot and fruit with their conversion in peach trees, Scientific Reports of Kyoto Prefecture University, 37, 1985 pp. 163-171.

[39] Stanhope K.L., Schwarz J.M., Keim N.L., Griffen S.C., Bermer A.A., Graham J.L., Hatcher B., Cox C.L., Dyachenko A., Zhang W., McGahan J.P., Seibert A., Krauss R.M., Chiu S., Schaefer E.J., Otokozawa M. Ai. S., Nakajima K., Nakano T., Beysen C., Hellerstein M.K., Berglund L., Havel P.J., Consuming fructosesweetened, not glucose-sweetened, beverages increases visceral adiposity and lipids and decreases insulin sensitivity in over weight/obese humans, J. Clinical Invest. 119 (2009) 1322-1334.

[40] Iglessias D.J., Cercos M., Colmenero-Flores J.M., Naranjo M.A., Riose G., Carrera E., Rivero O.R., Lliso I., Morillon R., Tadeo F.R., Talon M., Physiology of citrus fruiting, Braz. J. Plant Physiol. 19 (2007) 33-362.

[41] Davis P.L., Roe B., Bruemmer J.H., Biochemical changes in citrus fruits fruit during controlled-atmosphere storage, J. Food Sci. 38 (1973) 225-229.

[42] Sasson A., Monselise S.P., Organic acid composition of 'Shamouti' oranges at harvest and during prolonged postharvest storage, J. Amer. Soc. Hort. Sci. 102 (1977) 331-336.

[43] Echeverria E.D., Ismail. M., Changes in sugars and acids of fruits during storage, Proc. Fla. State Hortic. Soc. 100 (1987) 50-52.

[44] Huang R., Xia R., Hu L.L.Y., Wang M., Antioxidant activity and oxygen-scavenging system in orange pulp during fruit ripening and maturation, Sci Hortic. 113 (2007) 166-172.

Cite this article as: Saeed Ahmad, Zora Singh, Zafar Iqbal. Tree and cold storage influence on incidence of albedo breakdown, textural properties of the rind and fruit quality in 'Washington Navel' orange. Fruits 71 (2016) 131-139. 